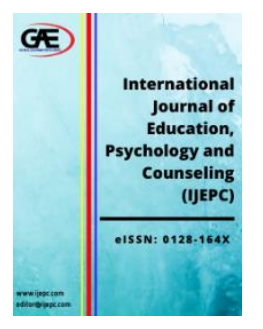

\author{
INTERNATIONAL JOURNAL OF \\ EDUCATION, PSYCHOLOGY \\ AND COUNSELLING \\ (IJEPC) \\ www.ijepc.com
}

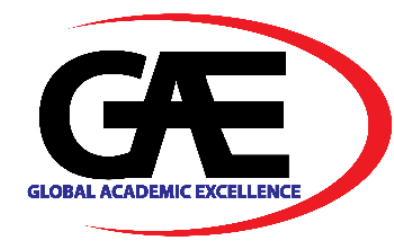

\title{
CURRENT TRENDS IN TPACK RESEARCH IN ENGLISH LANGUAGE EDUCATION: A SYSTEMATIC REVIEW OF LITERATURE FROM 2017 TO 2021
}

\author{
Lim Pei Sing ${ }^{1}$, Wardatul Akmam Din ${ }^{2 *}$, Nik Zaitun Nik Mohamed ${ }^{3}$, Suyansah Swanto ${ }^{4}$ \\ 1 Faculty of Psychology and Education, Universiti Malaysia Sabah, Malaysia \\ Email: mp1911203t@student.ums.edu.my \\ 2 Faculty of Psychology and Education, Universiti Malaysia Sabah, Malaysia \\ Email: wardadin@ums.edu.my \\ 3 Faculty of Psychology and Education, Universiti Malaysia Sabah, Malaysia \\ Email: nzaitun@ums.edu.my \\ 4 Faculty of Psychology and Education, Universiti Malaysia Sabah, Malaysia \\ Email: suyansah@ums.edu.my \\ Corresponding Author
}

\section{Article Info:}

\section{Article history:}

Received date: 11.09 .2021

Revised date: 10.10 .2021

Accepted date: 15.11 .2021

Published date: 30.11 .2021

\section{To cite this document:}

Lim, P. S., Din. W. A., Nik Mohamed, N. Z., \& Swanto, S. (2021). Current Trends In TPACK Research In English Language Education: A Systematic Review Of Literature From 2017 To 2021. International Journal of Education, Psychology and Counseling, 6 (43), 219-234.

DOI: $10.35631 /$ IJEPC.643018

\begin{abstract}
:
In this 21 st century, traditional ways of teaching and learning have been changed with the evolution of technology. Technological Pedagogical Content Knowledge (TPACK) is one of the conceptual models developed by researchers to facilitate teachers' professional development. It is believed that TPACK should be developed and mastered by teachers to achieve effective implementation of technology in teaching and learning. This systematic literature review aims to investigate current trends in TPACK research in English language education literature published between 2017 to 2021 . The keywords "Technological Pedagogical Content Knowledge", "TPACK", "English language", "ESL", "EFL" and "English teachers" with some modifications using "AND" and "OR" were used to obtain relevant articles from Scopus and ProQuest databases. The study inclusion process was done following the Preferred Reporting Items for Systematic Reviews and MetaAnalyses (PRISMA) 2020's framework. There were 14 articles yielded and included in this systematic literature review. The results show that TPACK studies in English language education were carried out worldwide. Moreover, half of the reviewed studies used pre-service English language teachers as the participants while others used in-service or both of them. Meanwhile, some studies used English language learners as the participants. In addition, there are a variety of methods including quantitative, qualitative and mixed method employed by the researchers of reviewed studies. We also identified 5 key
\end{abstract}




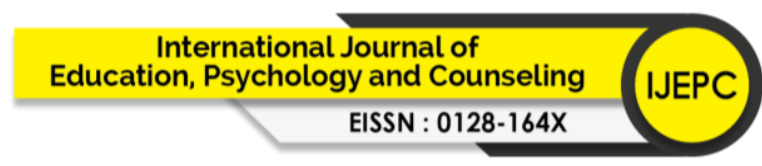

Volume 6 Issue 43 (November 2021) PP. 219-234

DOI 10.35631/IJEPC.643018

Special Issue: Issues and Challenges in English Education

This work is licensed under $\underline{\text { CC BY } 4.0}$ emerging themes of the reviewed studies including measurement of TPACK level (64\%), the relationship between TPACK and other variables (29\%), strategy to develop TPACK (29\%), implementation of TPACK (14\%) and development of TPACK instrument $(21 \%)$. This paper implies researchers in the English language education field, especially in Malaysia. Further studies on TPACK need to be conducted due to the limited current research in Malaysia.

Keywords:

EFL, English Language, ESL, English Teachers, TPACK

\section{Introduction}

Shyamlee and Phil (2012) believe that technology offers new ways of teaching and learning which can make the interaction in the classroom becomes more interesting and effective. In this 21 st century, the evolution of technology has changed the traditional ways of teaching and learning into online-based teaching and learning or e-learning. On top of that, the emergence of the Covid-19 pandemic around the world has affected the education field badly. Due to the sudden emergence of the Covid-19 pandemic around the world in earlier 2020, the implementation of e-learning has become the alternative way to make sure the teaching and learning still can go on and keep both the teachers and students safe. This situation has forced both teachers and students to accept sudden changes in the teaching and learning method from face-to-face classes to online classes (Md Lazim et al., 2021). This has also caused teachers to face a lot of challenges, given this happened suddenly without prior preparation (Rosalina et al., 2020).

It is found that implementing e-learning will be hard for teachers who have poor technological skills. Abd Samad et. al (2018)'s research found that teacher graduates have a moderate level in knowledge, skills and attitude in the implementation of e-learning. Besides, Mohalik and Sahoo (2020)'s research also found that the student teachers have poor digital skills such as knowing the use of applications and software for online learning. Furthermore, the result of the perception towards online learning showed that they think that curriculum cannot be effectively transacted through online mode. The major problems faced by teachers in implementing e-learning involving issues such as technological background skills and professional development. According to the analyses of The Teaching and Learning International Survey (TALIS) 2018 (as cited in Loi, 2020), teachers who had not used technologies in teaching as part of their formal education or training are found to face difficulties in implementing e-learning. Some studies found out that teachers' TPACK level are low and moderate (Mtebe \& Raphael, 2018; Agustini et al., 2019; Riandi et al., 2019). Other than that, Mohalik and Sahoo (2020) revealed that student teachers do not have TPACK.

Baber (2021) believes that teachers should acquire knowledge of technology and expertise to use it along with the knowledge of the subject. According to him, a teacher who has good pedagogical knowledge, content knowledge and technological knowledge, knows how to implement them in the classroom and has a positive attitude towards e-learning is considered a competent teacher. In addition, Mahdum (2015) believes that The Technological Pedagogical Content Knowledge (TPACK) should be developed and mastered by teachers to achieve effective implementation of e-learning. TPACK is one of the conceptual models Copyright (C) GLOBAL ACADEMIC EXCELLENCE (M) SDN BHD - All rights reserved 


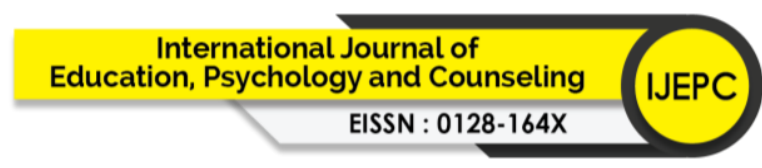

Volume 6 Issue 43 (November 2021) PP. 219-234

DOI 10.35631/IJEPC.643018

Special Issue: Issues and Challenges in English Education developed by researchers to facilitate teachers' professional development. TPACK is used to "measure the types of knowledge teachers have and need, to enable them to integrate technology with a complex, intricate and situated nature of teacher knowledge" (Misieng et al., 2018, p. 8). It is stated that this model describes "how teachers can use pedagogical and content knowledge to improve instructional practices, and how technology can support the implementation of the pedagogical and content knowledge" (Yang et al., 2019, p. 3).

Koehler et al.'s TPACK framework is built based on Mishra and Koehler (2006)'s formulation of the technological, pedagogical, and content knowledge (TPACK) framework. It is the extension of Shulman's (1986) characterization of teacher knowledge to clearly look at the role that knowledge about technology can play in effective teaching. Generally, there are three main knowledges in TPACK which are Technological Knowledge (TK), Pedagogical Knowledge (PK) and Content Knowledge (CK). These three fundamental knowledges overlapped and formed seven sub-components of knowledge. The seven subcomponents of knowledge of this framework are TK, PK, CK, Technological Pedagogical Knowledge (TPK), Technological Content Knowledge (TCK), Pedagogical Content Knowledge (PCK) and TPACK. TPACK is a beneficial framework to measure knowledge require to assist the integration of technology in educational practice (Horzum, 2013; Mtebe \& Raphael, 2018). A teacher with a high level of TPACK is considered as the one who masters knowledge to integrate technology in teaching and learning.

Therefore, we believe that it is important to investigate the current trends of TPACK studies. By providing insights into the current trends of TPACK studies particularly in English language education, researchers will be able to understand the recent TPACK research progress in the subject area. We then can identify the gaps in the existing TPACK research within the English language education field. Nevertheless, to the best of the researcher's knowledge, systematic literature reviews of current research on TPACK in the English language education context are limited. Therefore, this systematic literature review aims to investigate current trends in TPACK research in English language education literature published between 2017 to 2021. This systematic literature review will be guided by the following research question:

"What are the characteristics and emerging trends of research published from 2017 to 2021 in TPACK in English language Education?"

We will review the research published from the last 5 years that focuses on the characteristics and emerging topics on TPACK in English language education.

\section{Methodology}

A systematic literature review is "a way of synthesising scientific evidence to answer a particular research question in a way that is transparent and reproducible, while seeking to include all published evidence on the topic and appraising the quality of this evidence" (Lamé, 2019, p. 1633). The first step in this systematic literature review is to identify the keywords or a set of key terms to search for journals that had a connection with TPACK. The keywords that we used are "Technological Pedagogical Content Knowledge", "TPACK", "English language", "ESL", "EFL" and "English teachers" with some modifications using "AND" and "OR". The keywords were searched on Universiti Malaysia Sabah (UMS) 


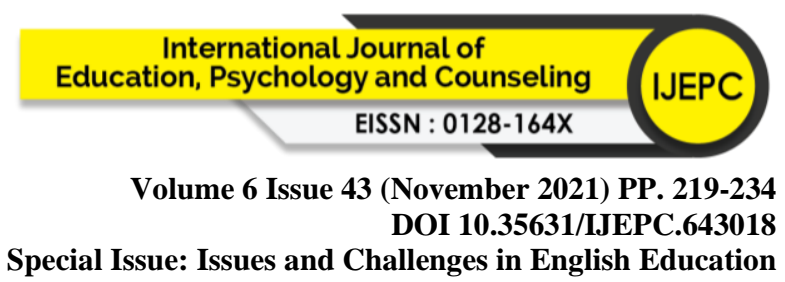
Library subscribed databases to obtain relevant articles. The databases to search the relevant articles only include Scopus and ProQuest. The Preferred Reporting Items for Systematic Reviews and Meta-Analyses (PRISMA) 2020's statement was used as the guideline for reporting this systematic literature review. The study inclusion flowchart following PRISMA framework is shown in Figure 1 below.

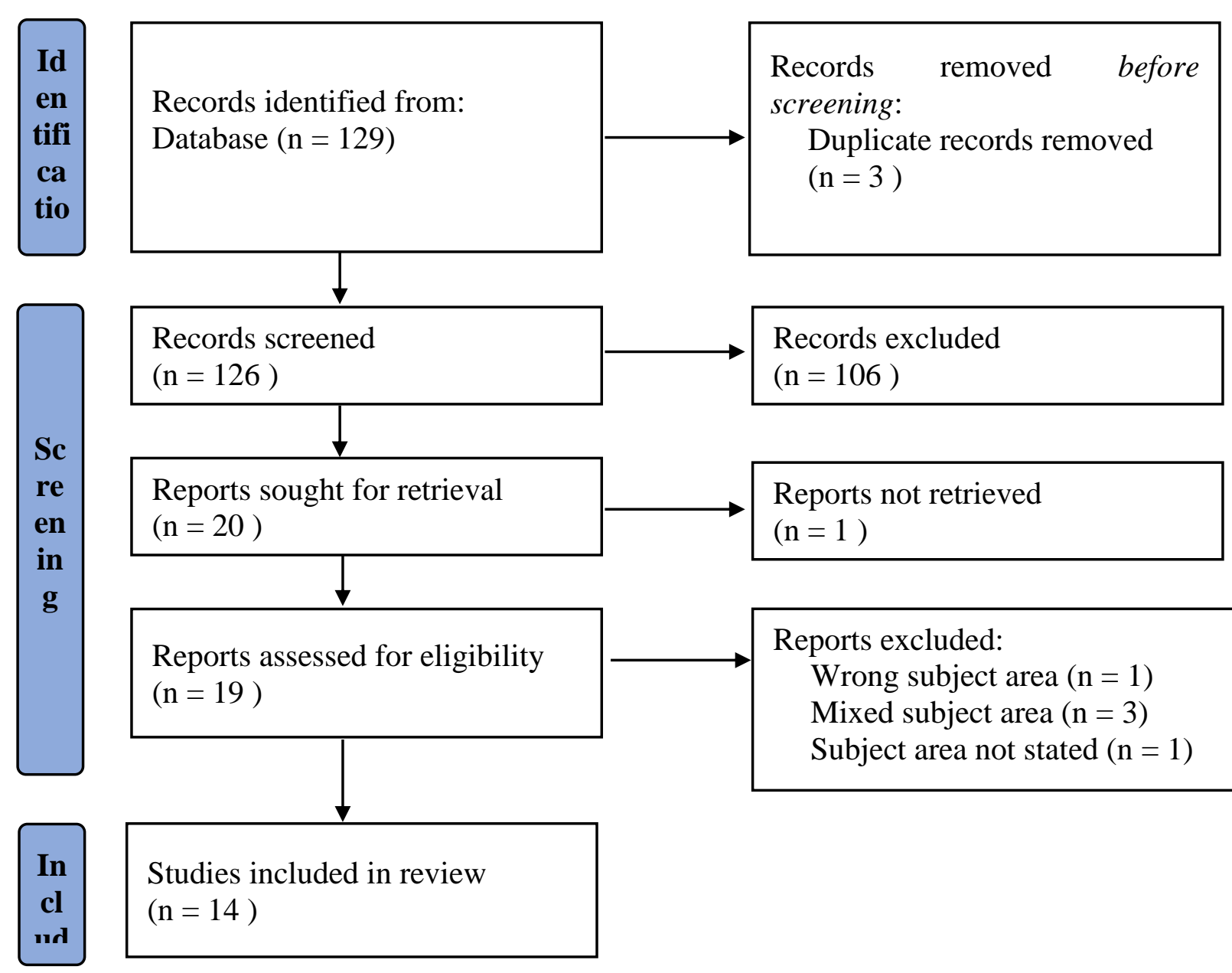

Figure 1: Study Inclusion Flowchart

Based on Figure 1, the study inclusion started with the identification process. We first applied all our limits such as year of publication, language and type of literature to retrieve relevant articles in the search process. There are several inclusion criteria in identifying articles to be included in the research synthesis, which are:

(i) The year of publication of the literature should be from 2017-2021.

(ii) The language of the literature should be in English.

(iii) The type of literature should be a journal article or scholarly article.

There was a total of 129 articles found by searching the keywords from Scopus (8 articles) and ProQuest (121 articles). The list of the articles was then exported to Microsoft Excel for further inclusion and exclusion process. To avoid reviewing duplicate articles, we removed 3 articles that appear more than once in the results. There were 126 articles left for screening 


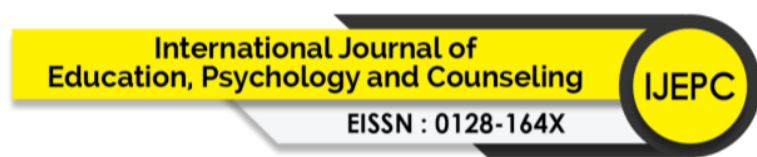

Volume 6 Issue 43 (November 2021) PP. 219-234

DOI 10.35631/IJEPC.643018

Special Issue: Issues and Challenges in English Education after the duplicate records were removed. The screening process focussed on the title and abstract to identify articles that are relevant to the research question. The articles that were not relevant to our research question were excluded. After the screening process, there were only 20 articles left for retrieval. There was only 1 article that we were unable to find the full text and thus 19 articles were available for reviewing the full text to assess their eligibility for inclusion in this systematic review. After reviewing all articles in the full-text screening stage for eligibility, the total number of articles excluded were 5 articles due to irrelevant subject area.

The final analysis yielded a total of 14 articles which were included in this systematic literature review. We then reported the main findings for each paper and then identified the characteristics of those studies including country, sample and method. We also analysed the research by grouping the research that has a similar topic. We considered the themes of each research by looking at the purpose and focus of the study. Then, the data are presented in tables and analysed quantitatively using Microsoft Excel. The result of the analysis was described quantitatively by comparing and contrasting the data in each category using charts and descriptive

percentages. 
Volume 6 Issue 43 (November 2021) PP. 219-234

DOI 10.35631/LJEPC 643018

Results and Discussion

Special Issue: Issues and Challenges in English Education

Table 1 below shows the characteristics and relevant findings of each reviewed study.

Table 1: Characteristics and Relevant Findings of Each Reviewed Study

\begin{tabular}{|c|c|c|c|c|c|}
\hline $\begin{array}{l}\text { Author \& } \\
\text { Year } \\
\end{array}$ & Title of Journal & Country & Sample & Method & Relevant Findings \\
\hline $\begin{array}{l}\text { R1 } \\
\text { Turgut (2017) }\end{array}$ & $\begin{array}{l}\text { Tracing preservice English } \\
\text { language teachers' } \\
\text { perceived TPACK in } \\
\text { sophomore, junior, and } \\
\text { senior } \\
\text { levels }\end{array}$ & Turkey & $\begin{array}{l}\text { Pre- } \\
\text { service } \\
\text { English } \\
\text { language } \\
\text { teachers }\end{array}$ & Mixed & $\begin{array}{l}\text { Experienced teachers were of significantly higher scores in } \\
\text { PK and PCK while novice teachers were of significantly higher } \\
\text { scores in TK, TCK, TPK, TPACK. Novice and experienced EFL } \\
\text { teachers favoured different professional development programs } \\
\text { tailored to their needs. They claimed that they could bridge the } \\
\text { gap in their knowledge through collaboration in professional } \\
\text { development courses. }\end{array}$ \\
\hline $\begin{array}{l}\text { R2 } \\
\text { Bostancioğlu } \\
\& \quad \text { Handley } \\
(2018)\end{array}$ & $\begin{array}{l}\text { Developing and validating } \\
\text { a questionnaire for } \\
\text { evaluating the EFL 'Total } \\
\text { PACKage': Technological } \\
\text { Pedagogical Content } \\
\text { Knowledge (TPACK) for } \\
\text { English as a Foreign } \\
\text { Language (EFL) }\end{array}$ & $\begin{array}{l}72 \text { different } \\
\text { countries }\end{array}$ & $\begin{array}{l}\text { In-service } \\
\text { English } \\
\text { language } \\
\text { teachers }\end{array}$ & Quar & $\begin{array}{l}\text { Turkish EFL teachers' TPACK skills and attitudes towards } \\
\text { technology were at a high level. Attitudes of Turkish EFL } \\
\text { teachers towards technology did not show a significant } \\
\text { difference according to gender, FATIH project training and } \\
\text { professional experience. TPACK skills of the teachers did not } \\
\text { differ significantly according to the professional experience. } \\
\text { There is a low, positive and significant relationship between } \\
\text { teachers' TPACK skills and attitudes towards technology. }\end{array}$ \\
\hline $\begin{array}{l}\text { R3 } \\
\text { Chuang, Ho, } \\
\text { Weng \& Liu } \\
(2018)\end{array}$ & $\begin{array}{lr}\text { High School Students' } \\
\text { Perceptions of } \\
\text { Teachers' } \\
\text { Knowledge in Technology- } \\
\text { Supported } & \text { Class } \\
\text { Environments } & \\
\end{array}$ & an & $\begin{array}{l}\text { English } \\
\text { language } \\
\text { learners }\end{array}$ & $\mathrm{Qu}$ & $\begin{array}{l}\text { The finding of this research had supported the face and content } \\
\text { validity of the developed TPACK questionnaire for English } \\
\text { teachers and this proved that the result had high reliability and } \\
\text { validity. Thus, it can be further used for the next study. }\end{array}$ \\
\hline $\begin{array}{l}\text { R4 } \\
\text { Drajati, Tan, } \\
\text { Haryati, } \\
\text { Rochsantining }\end{array}$ & $\begin{array}{l}\text { Investigating } \text { English } \\
\text { Language Teachers in } \\
\text { Developing } \\
\text { TPACK And Multimodal }\end{array}$ & donesia & $\begin{array}{l}\text { Pre- } \\
\text { service } \\
\text { and in- } \\
\text { service }\end{array}$ & Mixed & $\begin{array}{l}\text { The findings of the study revealed that the pre-service teachers } \\
\text { have a substantial understanding and mastery of TPACK. The } \\
\text { pre-service teachers revealed some effective technological } \\
\text { pedagogical content knowledge strategies used for teaching }\end{array}$ \\
\hline
\end{tabular}

Copyright $\odot$ GLOBAL ACADEMIC EXCELLENCE (M) SDN BHD - All rights reserved 
Volume 6 Issue 43 (November 2021) PP. 219-234

DOI 10.35631/LJEPC.643018

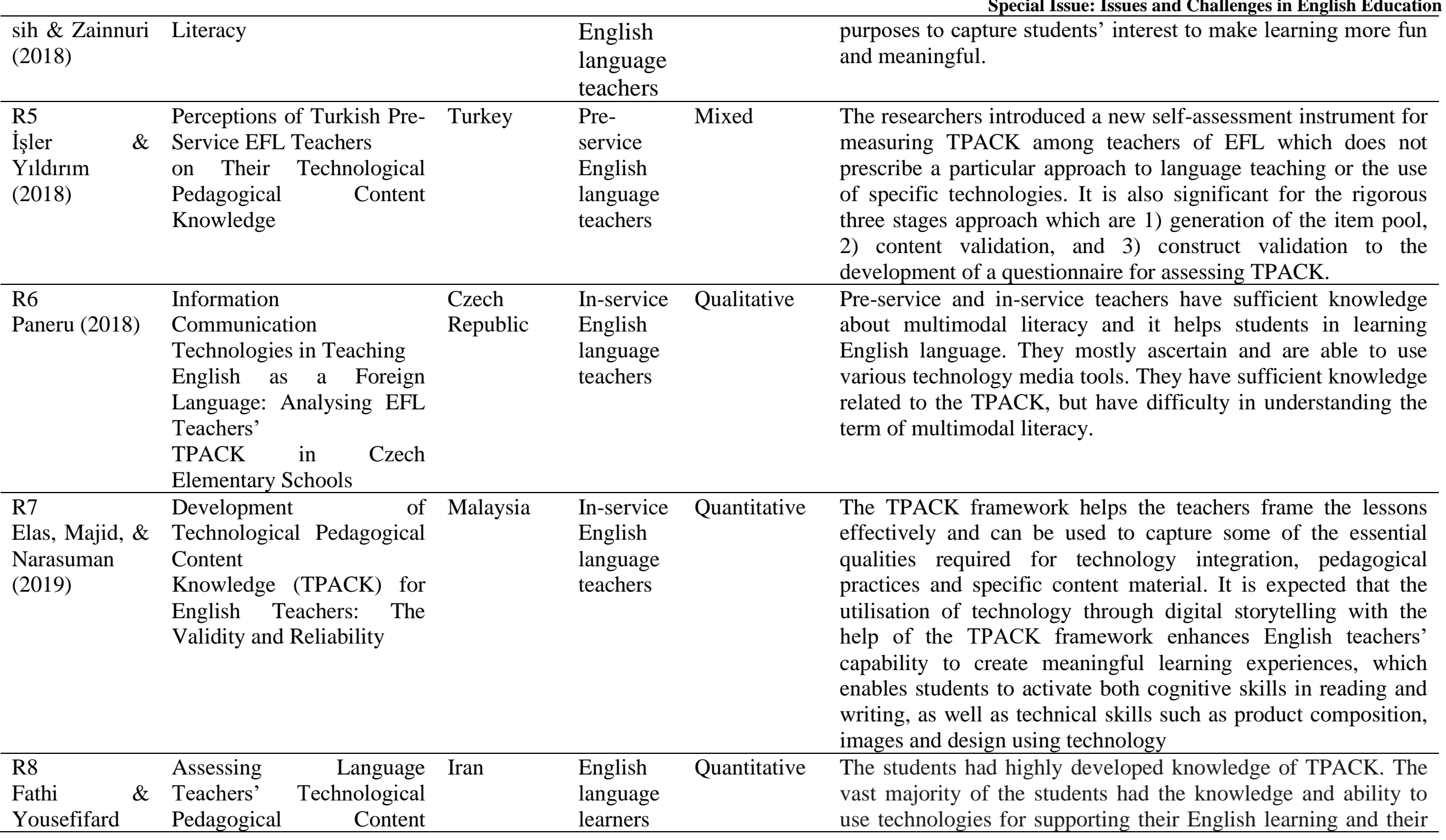

Copyright $\odot$ GLOBAL ACADEMIC EXCELLENCE (M) SDN BHD - All rights reserved 
Volume 6 Issue 43 (November 2021) PP. 219-234

DOI 10.35631/IJEPC.643018

Special Issue: Issues and Challenges in English Education

(2019) Knowledge (TPACK): EFL

Students' Perspectives future teaching. They see technology as a tool that can help them

to perform their teaching later when they become an English teacher and this suggests the students' positive attitude toward technology. However, they did not have sufficient knowledge when it came to solving or fixing problems related to the technology they used.

\begin{tabular}{llll}
\hline R9 & $\begin{array}{l}\text { The investigation of the Turkey } \\
\text { Kozikoğlu \& relationship between }\end{array}$ & $\begin{array}{l}\text { In-service } \\
\text { English } \\
\text { Babacan } \\
\text { (2019) }\end{array}$ \\
& $\begin{array}{l}\text { Turkish EFL teachers' } \\
\text { technological pedagogical }\end{array}$ & language \\
& content knowledge skills & \\
& and attitudes towards & \\
& technology
\end{tabular}

Reflective practices helped the teachers to describe and articulate their own experiences in teaching, learn from enacted experiences in the classroom, and apply learned practices in subsequent teaching. This virtuous cycle indicates that reflective practice is an essential mechanism for EFL teachers to become proficient in integrating technology in their teaching practices. Reflection enabled teachers to build connections among the different components of TPACK. As one of the tools of reflection on action,

group discussion brings confidence to the teacher in developing TPACK in their lesson plans.

\begin{tabular}{|c|c|c|c|c|c|}
\hline $\begin{array}{l}\text { R10 } \\
\text { Nazari, } \\
\text { Nafissi, Estaji } \\
\& \quad \text { Marandi } \\
(2019)\end{array}$ & $\begin{array}{l}\text { Evaluating novice and } \\
\text { experienced EFL teachers' } \\
\text { perceived TPACK for their } \\
\text { professional } \\
\text { development }\end{array}$ & Iran & $\begin{array}{l}\text { In-service } \\
\text { English } \\
\text { language } \\
\text { teachers }\end{array}$ & Mixed & $\begin{array}{l}\text { Most EFL students perceived that their EFL teachers excelled in } \\
\text { four components of TPACK such as TK, PK, CK, and PCK. The } \\
\text { teachers were perceived to be relatively less proficient in the } \\
\text { other three components of the scale such as TCK, TPK, and } \\
\text { TPACK. However, the students believed that their teachers } \\
\text { possessed above an average level of total TPACK which means } \\
\text { that their teachers were competent with regard to total TPACK. }\end{array}$ \\
\hline $\begin{array}{l}\text { R11 } \\
\text { Singh \& } \\
\text { Kasim (2019) }\end{array}$ & $\begin{array}{lr}\text { Pre-service } & \text { Teachers' } \\
\text { Mastery of Technological } \\
\text { Pedagogical } & \text { Content } \\
\text { Knowledge for Teaching } \\
\text { English Language }\end{array}$ & Malaysia & $\begin{array}{l}\text { Pre- } \\
\text { service } \\
\text { English } \\
\text { language } \\
\text { teachers }\end{array}$ & Qualitative & $\begin{array}{l}\text { This study conducted qualitative analysis and found two } \\
\text { different approaches in practice, which were categorised as } \\
\text { Formal Practice and Functional Practice. Teachers with } \\
\text { interactive digital pedagogical educational background and } \\
\text { experience, as opposed to those with formal technological } \\
\text { education, develop comprehensive TPACK and integrate it into } \\
\text { EFL classes in significant }\end{array}$ \\
\hline
\end{tabular}

Copyright $\odot$ GLOBAL ACADEMIC EXCELLENCE (M) SDN BHD - All rights reserved 
Volume 6 Issue 43 (November 2021) PP. 219-234

DOI 10.35631/1JEPC 643018

Special Issue: Issues and Challenges in English Education and interactive ways.

\begin{tabular}{|c|c|c|c|c|c|}
\hline $\begin{array}{l}\text { R12 } \\
\text { Amelia, } \\
\text { Rukmini, } \\
\text { Mujiyanto \& } \\
\text { Bharati (2021) }\end{array}$ & $\begin{array}{l}\text { Investigating the } \\
\text { Development of Teachers' } \\
\text { TPACK and the Adoption } \\
\text { of Digital Storytelling: A } \\
\text { Case Study of Teaching } \\
\text { English in Elementary } \\
\text { School }\end{array}$ & Indonesia & $\begin{array}{l}\text { In-service } \\
\text { English } \\
\text { language } \\
\text { teachers }\end{array}$ & Qualitative & $\begin{array}{l}\text { Students' perceptions of teachers' TK and KSU (an alternative } \\
\text { for PK) directly affect TPACK. SMK (an alternative for CK) } \\
\text { and KSU are indirectly related to TPACK with the association } \\
\text { significantly mediated by TK. They designed an instrument of } \\
\text { SPETK (students' perceptions of their English teachers' } \\
\text { knowledge) to determine students' perceptions of English } \\
\text { teachers' knowledge and to investigate how high school students } \\
\text { respond to their English teachers' instructions in technology- } \\
\text { supported class environments. }\end{array}$ \\
\hline $\begin{array}{l}\text { R13 } \\
\text { Sari, Drajati, } \\
\text { So \& Sumardi } \\
(2021)\end{array}$ & $\begin{array}{l}\text { Enhancing EFL Teachers' } \\
\text { Technological } \\
\text { Pedagogical Content } \\
\text { Knowledge (TPACK) } \\
\text { Competence Through } \\
\text { Reflective Practice }\end{array}$ & Indonesia & $\begin{array}{l}\text { In-service } \\
\text { English } \\
\text { language } \\
\text { teachers }\end{array}$ & Qualitative & $\begin{array}{l}\text { The quantitative data revealed high levels of perceptions on } \\
\text { TPACK competences, Meanwhile, the qualitative data supported } \\
\text { the high level of perceived TPACK competences and further } \\
\text { revealed that participants emphasized the place of personal } \\
\text { interest, experience, knowledge and access while singling out } \\
\text { educational support by their own instructors on the development } \\
\text { of TPACK. }\end{array}$ \\
\hline $\begin{array}{l}\text { R14 } \\
\text { Sofendi, } \\
\text { Inderawati \& } \\
\text { Vianty (2021) }\end{array}$ & $\begin{array}{l}\text { Technology Use and } \\
\text { Technology-Related } \\
\text { Learning Experiences as } \\
\text { Perceived by Indonesian } \\
\text { Tertiary EFL Students }\end{array}$ & Indonesia & $\begin{array}{l}\text { Pre- } \\
\text { service } \\
\text { English } \\
\text { language } \\
\text { teachers }\end{array}$ & Quantitative & $\begin{array}{l}\text { The results of the study indicated a nonlinear pattern of TPACK } \\
\text { development over time. There was a statistically significant } \\
\text { difference in all TPACK subdomains among sophomore, junior, } \\
\text { and senior pre-service teachers. Senior level pre-service teachers } \\
\text { self-rated themselves the highest having the subskills of } \\
\text { TPACK. }\end{array}$ \\
\hline
\end{tabular}




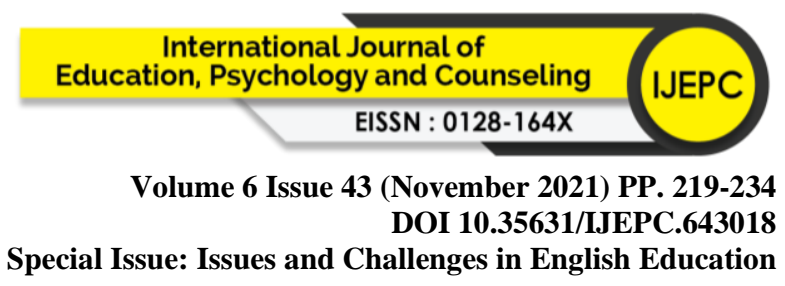

The Characteristics of The Reviewed Studies

Figure 2 below shows the percentage of countries involved in the reviewed studies.

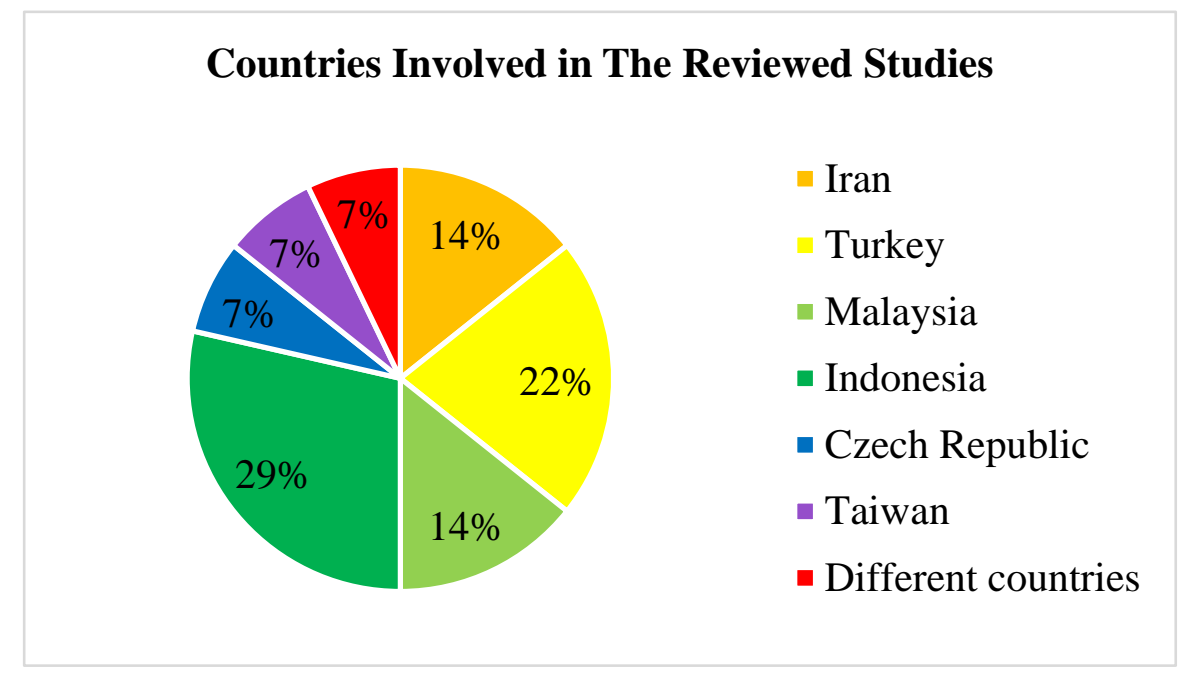

Figure 2: Countries Involved in The Reviewed Studies

Based on Figure 2, Czech Republic and Taiwan. Indonesia covered the highest percentage (29\%) followed by Turkey (22\%). Iran and Malaysia shared the same percentage which is $14 \%$ while the Czech Republic and Taiwan shared the same percentage of $7 \%$. There is only 1 study (7\%) that involved participants from different countries.

In addition, Figure 3 shows the percentage of samples involved in the reviewed studies.

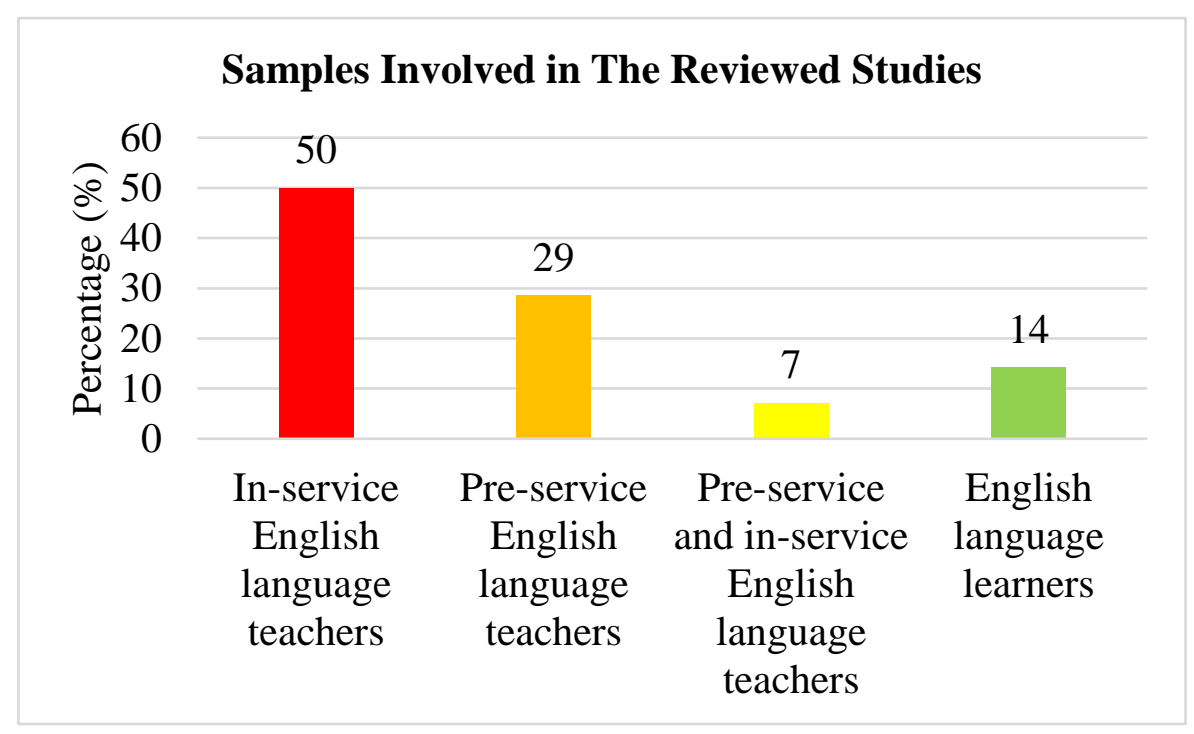

Figure 3: Samples Involved in The Reviewed Studies 


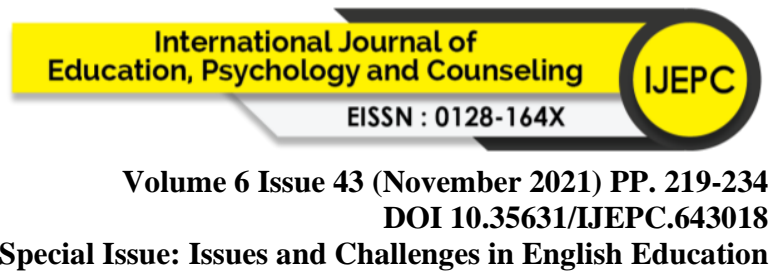

Based on Figure 3, half of the reviewed studies which is 7 out of 14 or $50 \%$ involved inservice English language teachers as the participants while $29 \%$ involved pre-service English language teachers. Only 1 study $(7 \%)$ involved both pre-service and in-service English language teachers. Besides, there are 2 studies (14\%) that involved English language learners as the participants.

Furthermore, Figure 4 shows the percentage of methods employed by the reviewed studies.

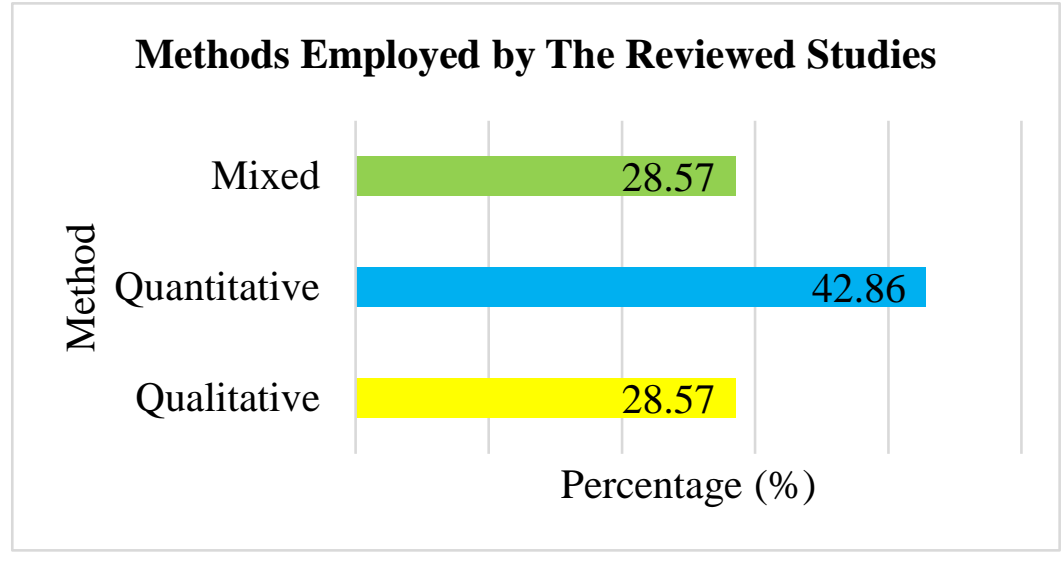

Figure 4: Methods Employed by The Reviewed Studies

As shown in Figure 4, most of the studies which are 6 out of 14 or $43 \%$ employed the quantitative method. There are 4 studies or $29 \%$ employed for each qualitative method and mixed method.

\section{Emerging Themes Appear in The Reviewed Studies}

Based on the analysis of reviewed studies related to TPACK research in English language education, we found out 5 key emerging themes. These emerging themes are:

(i) Measurement of TPACK level

(ii) Relationship between TPACK and other variables

(iii) Strategy to develop TPACK

(iv) Implementation of TPACK

(v) Development of TPACK instrument

The categorisation of each reviewed study according to their emerging themes is shown in Table 2.

Table 2: Themes of The Reviewed Studies

\begin{tabular}{|c|c|c|c|c|c|}
\hline \multicolumn{6}{|c|}{ Themes of the reviewed studies } \\
\hline Article & $\begin{array}{c}\text { Measurement } \\
\text { of TPACK } \\
\text { level }\end{array}$ & $\begin{array}{c}\text { Relationship } \\
\text { between } \\
\text { TPACK and } \\
\text { other } \\
\text { variables }\end{array}$ & $\begin{array}{l}\text { Strategy to } \\
\text { develop } \\
\text { TPACK }\end{array}$ & $\begin{array}{c}\text { Implementation } \\
\text { of TPACK }\end{array}$ & $\begin{array}{c}\text { Development } \\
\text { of TPACK } \\
\text { instrument }\end{array}$ \\
\hline $\mathrm{R} 1$ & / & / & & & \\
\hline R2 & & & & & / \\
\hline
\end{tabular}


Volume 6 Issue 43 (November 2021) PP. 219-234

DOI 10.35631/IJEPC.643018

R3

$\mathrm{R} 4$

R5

R6

R7

R8

R9

R10

R11

R12

R13

R14

Total

Article

Percentage

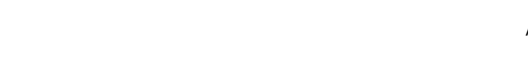

1

1

l 1

Based on Table 2, more than half which is $64 \%$ of the reviewed studies focusing on the measurement of TPACK level. 2 themes have the same percentage of $29 \%$ of reviewed studies which are the relationship between TPACK and other variables, and the strategy to develop TPACK. Besides, the main focus of $14 \%$ and $21 \%$ of reviewed studies are on implementation of TPACK and development of TPACK instrument respectively.

\section{Measurement of TPACK Level}

There are 9 (R1, R3, R4, R5, R8, R9, R10, R11, R14) out of 14 reviewed articles that measured TPACK level in various ways. Based on the analysis, there are two main ways to measure participants' TPACK level which are through perception and implementation. There are 6 reviewed studies (R1, R3, R4, R5, R8, R10, R14) measure TPACK level through selfperception whereas 3 reviewed studies (R9, R11, R14) measure TPACK level through implementation. The measurement of TPACK level through perception means that the participants make a perception of their TPACK level. They answer a questionnaire to identify their self-perceived TPACK. We found that all self-perceived TPACK is measured using questionnaires. As for the measurement of TPACK through implementation, TPACK level is measured based on the implementation of classroom practices that reflect their TPACK competency. Out of those 9 reviewed articles, 5 of them identify pre-service English language teachers' TPACK (R1, R5, R8, R11, R14), 3 of them identify in-service English language teachers' TPACK (R3, R9, R10), and 1 of them (R4) identify both pre-service and in-service English language teachers' TPACK.

\section{Relationship between TPACK and Other Variables}

Based on the reviewed studies, there are 4 studies (R1, R3, R9, R10) that investigated the relationship between TPACK and other variables. There are 2 reviewed studies (R1, R10) that identified the relationship between TPACK and the demographic characteristics which are seniority and teaching experience. Another reviewed study (R3), on the other hand, investigated the relationship between TPACK and other subcomponents of TPACK. In addition, there was a reviewed study (R9) that found out the relationship between TPACK 


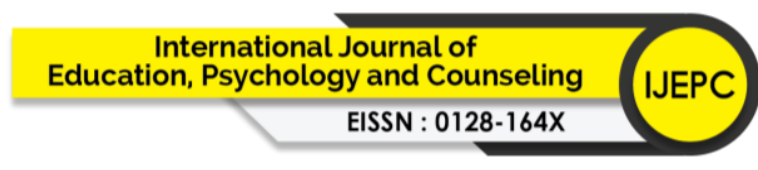

Volume 6 Issue 43 (November 2021) PP. 219-234

DOI 10.35631/IJEPC.643018

Special Issue: Issues and Challenges in English Education

and attitudes towards technology. This means that demographic characteristics, components of TPACK and other technology-related variables can be predictors of TPACK.

\section{Strategy to Develop TPACK}

There are several reviewed studies (R5, R6, R10, R13) that suggested some strategies to develop TPACK. One of the reviewed studies (R5) pointed out the importance of teacher education programs in developing pre-service English language teachers' TPACK. The steps that can be taken include teaching pre-service teachers explicitly how to combine technology, content and pedagogy and providing opportunities to becoming the designers of technologically mediated materials and experiencing technology-assisted instruction through the use of these materials at practicum schools (İşler \& Yıldırım, 2018). Another reviewed study (R6) stated two ICT practices in developing TPACK which are formal practices of ICT in EFL class, and functional practices of ICT in EFL class. In addition, there is also a reviewed study (R10) that listed out different professional developments separately for novice and experienced English language teachers. Meanwhile, another reviewed study (R13) examined how reflective practices can be an effective strategy in enhancing TPACK.

\section{Implementation of TPACK}

The implementation of TPACK means how teachers "apply TPACK in their teaching" (Setiawan et al., 2019, p. 4). There is 1 reviewed study (R4) that described the implementation of TPACK framework in English language teaching through several technology tools such as blog, mediated online discussion, text to speech software, video, social network and presentation tools (Drajati et al., 2018). Apart from that, another reviewed study (R12) discovered the implementation of 'digital narrative storytelling' by using TPACK as the framework. They believe that TPACK framework "can be used to capture some of the essential qualities required for technology integration, pedagogical practices and specific content material" (Amelia et al., 2021, p. 708).

\section{Development of TPACK Instrument}

Moreover, there are also several reviewed studies focus on the development of TPACK instrument. For example, two reviewed studies (R2, R7) developed and validated selfassessment instruments to measure English language teachers' TPACK. There is also another reviewed study (R3) that developed and validated an instrument for assessing high school students' perceptions of the knowledge possessed by English teachers which is made up of TPACK constructs. Bostancioğlu \& Handley (2018) pointed out the rigorous three stages approach to the development of a questionnaire for assessing TPACK including (i) generation of the item pool, (ii) content validation and (iii) construct validation.

\section{Conclusion}

This systematic literature review aims to investigate current trends in TPACK research in English language education literature published between 2017 to 2021. Table 3 below shows the overall results of the review. 
Volume 6 Issue 43 (November 2021) PP. 219-234

DOI 10.35631/IJEPC.643018

Special Issue: Issues and Challenges in English Education

Table 3: Overall Results of the Systematic Literature Review

\begin{tabular}{|c|c|c|c|}
\hline \multicolumn{3}{|c|}{ Main finding } & Percentage \\
\hline \multirow{14}{*}{$\begin{array}{c}\text { Characteristics of } \\
\text { the Reviewed } \\
\text { Studies }\end{array}$} & \multirow{7}{*}{$\begin{array}{c}\text { Countries } \\
\text { involved }\end{array}$} & Indonesia & $29 \%$ \\
\hline & & Turkey & $22 \%$ \\
\hline & & Iran & $14 \%$ \\
\hline & & Malaysia & $14 \%$ \\
\hline & & Czech Republic & $7 \%$ \\
\hline & & Taiwan & $7 \%$ \\
\hline & & Different countries & $7 \%$ \\
\hline & \multirow{4}{*}{$\begin{array}{l}\text { Samples } \\
\text { involved }\end{array}$} & In-service teachers & $50 \%$ \\
\hline & & Pre-service teachers & $29 \%$ \\
\hline & & Learners & $14 \%$ \\
\hline & & Pre-service \& In-service teachers & $7 \%$ \\
\hline & \multirow{3}{*}{$\begin{array}{l}\text { Methods } \\
\text { employed }\end{array}$} & Quantitative & $43 \%$ \\
\hline & & Qualitative & $29 \%$ \\
\hline & & Mixed & $29 \%$ \\
\hline \multirow{5}{*}{$\begin{array}{c}\text { Emerging Themes } \\
\text { Appear in The } \\
\text { Reviewed Studies }\end{array}$} & \multicolumn{2}{|c|}{ Measurement of TPACK level } & $64 \%$ \\
\hline & \multicolumn{2}{|c|}{ Relationship between TPACK and other variables } & $29 \%$ \\
\hline & \multicolumn{2}{|c|}{ Strategy to develop TPACK } & $29 \%$ \\
\hline & \multicolumn{2}{|c|}{ Development of TPACK instrument } & $21 \%$ \\
\hline & \multicolumn{2}{|c|}{ Implementation of TPACK } & $14 \%$ \\
\hline
\end{tabular}

Over these 5 years, current trends in TPACK research in English language education show variability in the characteristics and emerging themes. First and foremost, the results show that TPACK studies in English language education were carried out worldwide. Based on the reviewed studies, there are Indonesia, Turkey, Iran, Malaysia, Czech Republic and Taiwan that involved in carrying out TPACK research in English language education. There is also a study that was carried out involving 72 different countries around the world. Moreover, half of the reviewed studies used pre-service English language teachers as the participants while others used in-service or both of them. Meanwhile, some studies used English language learners as the participants. In addition, there are a variety of methods including quantitative, qualitative and mixed method employed by the researchers of reviewed studies. We also identified 5 key emerging themes of the reviewed studies including measurement of TPACK level (64\%), the relationship between TPACK and other variables (29\%), strategy to develop TPACK (29\%), implementation of TPACK (14\%) and development of TPACK instrument $(21 \%)$.

However, this systematic literature review only involved 14 articles from 2 databases which are Scopus and ProQuest. Future researchers should involve more databases and resources such as ERIC, Web of Science, Google Scholar and more to get a broader overview of the studies. Apart from that, this review is limited to the investigation of general TPACK research in English language education. Future research focusing on a specific theme such as the relationship between TPACK and demographic variables and other technology-based variables can be conducted. This paper implies researchers in the English language education field, especially in Malaysia. Further studies on TPACK need to be conducted due to the limited current research in Malaysia. 


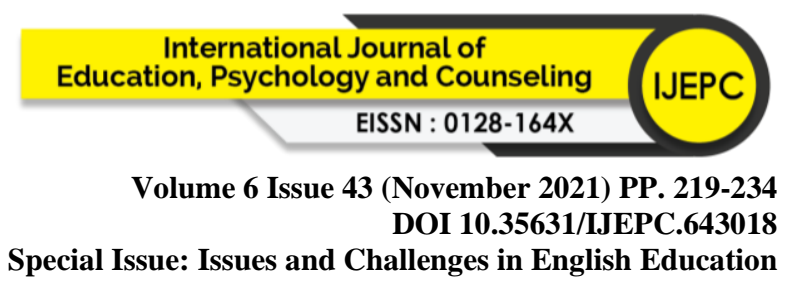

\section{References}

Abd Samad, N., Wan Ahmad, W. M. R., Harun, H., Mohd. Noor, S. N. F., Ismail, A., Abd. Rahman, M. W., \& Justin, R. (2018). The readiness level of using e-learning among teacher graduate programme (TGP). MATEC Web of Conferences, 150, 1-5.

Agustini, K., Santyasa, I. W., \& Ratminingsih, N. M. (2019). Analysis of competence on "TPACK": 21st century teacher professional development. Journal of Physics: Conference Series, 1387, 1-9.

Amelia, P., Rukmini, D., Mujiyanto, J., \& Bharati, D. A. L. (2021). Investigating the development of teachers' TPACK and the adoption of digital storytelling: A case study of teaching English in elementary school. The Journal of Asia TEFL, 18(2), 701-710.

Baber, H. (2021). Social interaction and effectiveness of the online learning - A moderating role of maintaining social distance during the pandemic Covid-19. Asian Education and Development Studies. doi:https://doi.org/10.1108/AEDS-09-2020-0209

Bostancioğlu, A., \& Handley, Z. (2018). Developing and validating a questionnaire for evaluating the EFL 'Total PACKage': Technological pedagogical content knowledge (TPACK) for English as a foreign language (EFL). Computer Assisted Language Learning, 31(2), 1-27.

Drajati, N. A., Tan, L., Haryati, S., Rochsantiningsih, D., \& Zainnuri, H. (2018). Investigating English language teachers in developing TPACK and multimodal literacy. Indonesian Journal of Applied Linguistics, 7(3), 575-582.

Horzum, M. B. (2013). An investigation of the technological pedagogical content knowledge of pre-service teachers. Technology, Pedagogy and Education, 22(3), 303-317.

İşler, C., \& Yıldırım, O. (2018). Perceptions of Turkish pre-service EFL teachers on their technological pedagogical content knowledge. Journal of Education and Future, 13, 145-160.

Lamé, G. (2019, Aug 2019). Systematic literature reviews: An introduction. Paper presented at the International Conference on Engineering Design, Delft, Netherlands. Retrieved from https://hal.archives-ouvertes.fr/hal-02196760/document

Loi, M. (2020). Many teachers don't use technology in the classroom often: Here's how to change that. Retrieved from https://www.google.com/amp/s/oecdedutoday.com/teachers-use-technologyclassroomchange/amp/

Mahdum. (2015). Technological pedagogical and content knowledge (TPACK) of English teachers in Pekanbaru, Riau, Indonesia. Mediterranean Journal of Social Sciences, 6(5), 168-176.

Md Lazim, C. S. L., Ismail, N. D., \& Afiq Khamar Tazilah, M. D. (2021). Application of technology acceptance model (TAM) towards online learning during Covid-19 pandemic: Accounting students perspective. International Journal of Business, Economics and Law, 24(1), 13-20.

Mishra, P., \& Koehler, M. J. (2006). Technological pedagogical content knowledge: A framework for teacher knowledge. Teachers College Record, 108(6), 1017-1054.

Misieng, J., Ramanair, J., \& Rethinsamy, S. (2018). Measuring teachers' readiness to use technology: Pedagogical and content knowledge (TPACK) pilot study. Journal of IT in Asia, 8, 7-13. 


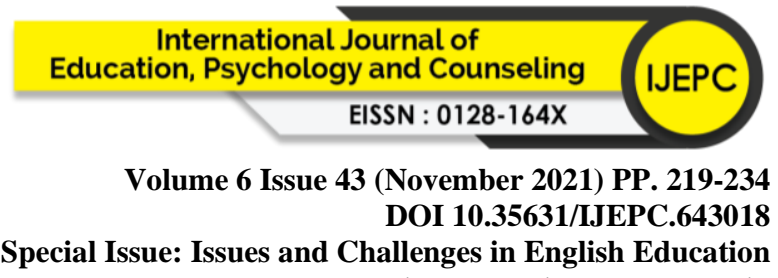

Mohalik, R., \& Sahoo, S. S. (2020). E-readiness and perception of student teachers' towards online learning in the midst of Covid-19 pandemic. SSRN Electronic Journal. doi:https://dx.doi.org/10.2139/ssrn.3666914.

Mtebe, J. S., \& Raphael, C. (2018). Eliciting in-service teachers' technological pedagogical content knowledge for 21st-century skills in Tanzania. Journal of Learning for Development, 5(3), 263-279.

Riandi, Apriliana, V., \& Purwianingsih, W. (2018). The analysis of 21 st century teachers' ability in technological pedagogical content knowledge. Advances in Social Science, Education and Humanities Research, 212, 275-278.

Rosalina, E., Nasrullah \& Elyani, E. K. (2020). Teacher's challenges towards online learning in pandemic era. Linguistics, Literature and English Teaching Journal, 10(2), 71-88.

Setiawan, H., Philipson, H., Sudarmin \& Isnaeni, W. (2019). Current trends in TPACK research in science education: A systematic review of literature from 2011 to 2017. ICOMSET2018, 1317, 1-6.

Shulman, L. E. (1986). Those who understand: Knowledge growth in teaching. Educational Research, 15(2), 4-14.

Shyamlee, S. D., \& Phil, M. (2012). Use of technology in English language teaching and learning: An analysis. 2012 International Conference on Language, Medias and Culture, 33, 150-156.

Yang, J., Wang, Q., Wang, J., Huang, M., \& Ma, Y. (2019). A study of K-12 teachers' TPACK on the technology acceptance of e-schoolbag. Interactive Learning environments. doi:https://doi.org/10.1080/10494820.2019.1627560. 